\title{
Faktor-Faktor yang Berhubungan dengan Onset Laktasi pada Ibu Nifas 0-3 Hari Di Ruang Rawat Ibu BLUD Rumah Sakit Ibu dan Anak Banda Aceh
}

\author{
Factors Associated with Lactation Onset in Postpartum Mothers 0-3 Days in \\ Mother's Nursing Room BLUD Mother and Child Hospital Banda Aceh
}

\section{Chairanisa Anwar ${ }^{* 1}$, Munira ${ }^{2}$}

\footnotetext{
${ }^{1}$ Program Studi D-IV Bidan Pendidik, Fakultas Ilmu Kesehatan, Universitas Ubudiyah Indonesia, Banda Aceh, Indonesia ${ }^{2}$ Program Studi D-IV Kebidanan, Politekhnik Kesehatan Kemenkes Aceh, Banda Aceh, Indonesia
}

*Korespondensi Penulis: chaira.anwar@uui.ac.id

\begin{abstract}
Abstrak
Pemberian ASI eksklusif secara nasional 32\% masih sangat jauh dari target nasional sebesar $80 \%$. Beberapa penelitian menunjukkan bahwa onset laktasi berperan dalam pemberian makanan prelaktal ataupun susu formula. Segi lain promosi yang tidak terkendali dari susu formula dapat mengubah keputusan ibu untuk menyusui sendiri bayinya dan dapat menghambat terjadinya proses laktasi sehingga bayi segera diberikan pengganti air susu ibu. Dengan diketahuinya hubungan paritas dan metode persalinan dengan onset laktasi diharapkan dapat meningkatkan pemberian ASI secara penuh pada neonatus di Kota Banda Aceh. Tujuan Penelitian untuk mengetahui hubungan paritas dan metode persalinan dengan onset laktasi pada ibu nifas di Ruang Rawat Ibu BLUD RSIA tahun 2016. Hasil Penelitian tidak terdapat hubungan yang bermakna antara paritas dengan onset laktasi pada ibu nifas, dimana diperoleh nilai $\mathrm{p}=0.718(\mathrm{P}>0.05)$ dan terdapat hubungan yang bermakna antara metode persalinan dengan onset laktasi pada ibu nifas, dimana diperoleh nilai $\mathrm{P}=$ $0.018(\mathrm{P}<0.05)$.
\end{abstract}

Kata kunci: paritas, metode persalinan, onset laktasi, ibu nifas.

\begin{abstract}
$32 \%$ of national exclusive breastfeeding is still very far from the national target of $80 \%$. Several studies have shown that the onset of lactation plays a role in prelactal feeding or formula milk. Another aspect of uncontrolled promotion of formula milk can change the mother's decision to breastfeed herself and can inhibit the occurrence of the lactation process so that the baby is immediately given a replacement for breast milk. By knowing the relationship between parity and the method of delivery with lactation onset it is expected to increase breastfeeding in full in neonates in Banda Aceh City. Purpose of Study to determine the relationship between parity and lactation onset labor methods in postpartum mothers in the Nursing Room of the BLIA Hospital in 2016. Result of Research there was no significant relationship between lactation onset parity in postpartum mothers, where $p=0.718(P>0.05)$ was obtained and there was a significant correlation between lactation onset delivery methods in postpartum mothers, where $P=0.018(P<0.05$.
\end{abstract}

Keywords: parity, method of delivery, lactation onset, postpartum mother 


\section{PENDAHULUAN}

Berdasarkan penelitian World Health Organization (WHO), 2000 di enam negara berkembang resiko kematian bayi diantara usia 9-12 bulan meningkat 40\% jika bayi tersebut tidak disusui. Sedangkan jika usia bayi dibawah dua bulan, angka kematian ini meningkat menjadi 48\% (Roesli, 2008). Jika seluruh bayi mendapatkan ASI eksklusif di enam bulan pertama kehidupannya dan hanya diberikan ASI dan tidak diberikan cairan lain maka hal itu dapat menyelamatkan 12 juta anak-anak setiap tahunnya, kemudian anak-anak yang melanjutkan menyusui sampai 2 tahun maka kesehatan dan perkembangan dari beberapa anak akan menjadi lebih baik (UNICEF, 2007).

Survei Demografi Kesehatan Indonesia tahun 2007 menyebutkan bahwa Angka Kematian Bayi (AKB) 34/1000 Kelahiran Hidup (KH), sedangkan target Rencana Pembangunan Jangka Menengah Nasional (RPJMN) Kementerian Kesehatan tahun 2014 AKB sebanyak 24/1000 KH, sekitar 40\% kematian Balita terjadi pada satu bulan pertama kehidupan bayi. United Nations Children Education and Fund (UNICEF) memperkirakan pemberian Air Susu Ibu (ASI) eksklusif sampai enam bulan dapat mencegah kematian 1,3 juta anak berusia dibawah lima tahun (BPS et al.,2008). Angka ini jauh lebih tinggi apabila dibandingkan dengan negara Asia Tenggara seperti Singapura 1/1000 KH dan Filiphina 18/ 1000 KH (Roesli, 2008).

Berdasarkan data Riskesdas tahun 2010 menunjukkan pemberian ASI di Indonesia saat ini memprihatinkan, bayi yang menyusu eklusif sampai 6 bulan hanya 15,3\%. Rendahnya pemberian ASImerupakan ancaman bagi tumbuh kembang anak yang akanberpengaruh pada pertumbuhan dan perkembangan kualitas sumber daya manusia secara umum. Seperti diketahui jika bayi tidak diberikan ASI dan makanan pendamping yang baik dan tepat setelah usia 6 bulan secara teratur dapat menyebabkan bayi mengalami kekurangan gizi, dan pemberian ASI juga diketahui bisa mencegah kematian bayi (Antaranews, 2011).

Menurut Hruschka et al (2003) tentang Faktor keberlangsungan ASI eksklusif lain adalah Onset laktasi yaitu masa permulaan untuk memperbanyak air susu sampai air susu keluar pertama kali atau persepsi ibu kapan air susunya keluar (come in) yang ditandai dengan payudara terasa keras, berat, bengkak sampai air susu atau kolostrum keluar.

Berdasarkan hasil Penelitian Hruschka et al (2003) yang berjudul Delayed Onset Of Lactation And Risk Of Ending Full Breast Feeding Early In Rural Guetamalamenunjukkan 
bahwa pemberian ASI predominat yaitu 2.3\% dengan kategori pemberian air putih 4.0\%, cairan yang berisi vitamin dan teh $4.5 \%$ dan susu formula $2.1 \%$, pemberian ASI predominant lebih banyak terjadi pada ibu multipara, persalinan pervaginam, dan yang dilakukan IMD, dari penelitian tersebut terdapat hubungan signifikan antara waktu onset laktasi dengan pemberian ASI eksklusif bayi usia 6 bulan.

Satu jam pertama bayi akan belajar menyusu atau membiasakan menghisap puting susu dan mempersiapkan ibu mulai memproduksi ASI kolostrum (Gupta, 2007). Pemberian awal air susi ibu sangat dianjurkan karena banyak memberikan manfaat kesehatan untuk ibu dan bayi. Sejak lahir bayi dibekali reflex kehidupan untuk mempertahankan kehidupannya. Minggu pertama setelah persalinan merupakan periode kritis untuk menyusui. Produksi ASI biasanya sedikit dalam 1-2 hari pertama setelah bersalin, tetapi kemudian meningkat pada hari ke 2-3 sebagai respon dari penurunan hormone progesteron. Pada masa ini ibu dan bayinya belajar bagaimana menyusui (Dewey et al.,2003).

Di Amerika Serikat dilaporkan bahwa pelaksanaan inisiasi menyusu dini sangat rendah dan menyebabkan onset laktasi yang lebih lama (ScottandBinns, 2007). Hasil penelitian menunjukkan kesadaran dari tenaga kesehatan untuk melaksanakan inisiasi menyusu dini pada 30 menit pertama sangat rendah yaitu hanya sekitar 20,8\% tenaga kesehatan yang melaksanakannya (Khassawneh et al.,2006).

Hasil penelitian bahwa pemberian ASI pada hari pertama akan menyelamatkan $16 \%$ kematian neonatal dan jika menyusu dini dalam 1 jam pertama akan menyelamatkan 22\% kematian balita pertahun dari kematian (Edmond et al., 2006). Menurut Gartner et al, 2005 dan Gupta, 2007 yang dikutip oleh Hatini (2011) bahwa Perlindungan ASI akan semakin meningkat sejalan dengan makin mudanya usia pemberian ASI pada bayi. Beberapa penelitian membuktikan bahwa manfaat pemberian ASI dini yaitu untuk keberlangsungan pemberian ASI eksklusif, mendapatkan kekebalan terhadap berbagai penyakit, mencegah hipotermia, refleks isapan pada puting susuibuserta pengeluaran hormon oksitosin akan merangsang produksi ASI.

Penelitian Chapman and Escamilla (1999) pada persepsi ibu tentang onset laktasi >3 hari, $24 \%$ ibu memilih untuk tidak menyusui bayinya. Penelitian lainnya mengungkapkan bahwa onset menyusui yang lebih lambatberhubungan dengan persepsi ibu bahwa ASI tidak mencukupi kebutuhan bayinya dan kehilangan kepercayaan diri akan kemampuan ibu untuk menyusui bayinya. Selain itu usia ibu yang masih muda dan pendidikan yang rendah 
berhubungan dengan pemberian ASI yang singkat (Hruschka et al., 2003). Penyebab lain yang juga menjadi kendala adalah pada ibu yang persalinan dengan metode seksio sesarea onset menyusui lebih lambat dibandingkan yang persalinan pervaginam (Dewey, 2001).

Penelitian Ahluwalia et al.(2005), menemukan bahwa 13\% ibu yang berhenti menyusui bayinya pada bulan pertama disebabkan bayi yang tidak dapat menyusu dan persepsi mereka tentang produksi air susu ibu tidak cukup untuk bayinya. Wallace et al. (2006) menemukan bahwa terjadi penurunan pemberian ASI menjadi 54\% pada dua minggu pertama setelah lahir dari 71\% pada saat lahir ( Hatini, 2011).

Segi lain promosi yang tidak terkendali dari susu formula dapat mengubah keputusan ibu untuk menyusui sendiri bayinya dan dapat menghambat terjadinya proses laktasi sehingga bayi segera diberikan pengganti air susu ibu. Hasil penelitian menemukan bahwa anak-anak di Brazil sebanyak 25\% menerima air putih dan teh herbal, serta 22\% diberikan susu formula pada satu bulan pertama kehidupannya. Pada penelitian di Korea Utara implementasi penekanan promosi susu formula tidak berjalan sebagaimana mestinya, karena sampai tahun 2006 hanya 1,8\% yaitu 57 dari 3126 fasilitas pelayanan ibu dan anak yang mendapatkan akreditasi sayang bayi (Hatini, 2011).

Di Indonesia implementasi tentang peraturan Menteri Kesehatan Republik Indonesia No. 240/Menkes/Per/V/85 tentang pengganti air susu ibu tidak berjalan dengan semestinya. Hal ini dapat dilihat dimana di tempat pelayanan kesehatan masih dilakukan promosi susu formula, bahkan tidak jarang bidan praktek memberikan susu formula pada bayi baru lahir serta ibu dan bayi tidak difasilitasi untuk pelaksanaan inisiasi menyusu dini. Hasil Survei Demografi dan Kesehatan Indonesia (SDKI)2007 bayi yang lahir di fasilitas kesehatan mendapatkan prelacteal feeding sekitar 70,1\% (BPS and Macro International, 2008).

Data terakhir cakupan pemberian ASI eksklusif (0-6 bulan) di Indonesia sebesar 61,5\%. Provinsi dengan cakupan terendah adalah Aceh 49,6\%. Sedangkan provinsi dengan cakupan tinggi diantaranya adalah Provinsi Nusa Tenggara Barat 79.7\%, Nusa Tenggara Timur 77,4\% dan Bengkulu 77,5\%, terlihat dari data tersebut Provinsi Aceh adalah cakupan terendah di Indonesia (Susenas, 2010).

Hasil studi pendahuluan di Rumah Sakit Umum Ibu dan Anak (RSIA) selama tahun 2016 dari bulan Januari sampai Maret ditemukan data tentang jumlah cakupan ibu nifas yang memberikan ASI pada bayinya berjumlah 1.181 orang. Dengan jumlah data tentang 
onset laktasi yang menunjukkan pengeluaran ASI sebelum 3 hari pada ibu nifas berjumlah $1047(88,65 \%)$, dan onset Laktasi yang menunjukkan pengeluaran ASI > 3 hari berjumlah $134(11,35 \%)$ menunjukkan bahwa tahap proses onset laktasi yang lebih dari 3 hari (lambat). Terlihat dari data diatas peneliti tertarik untuk mengetahui lebih lanjut tentang Faktor-Faktor Apa Saja Yang Berhubungan Dengan Onset Laktasi Pada Ibu Nifas 0-3 Hari Di Ruang Rawat Ibu Rumah Sakit Ibu Dan Anak Banda Aceh.

\section{METODE PENELITIAN}

Penelitian ini merupakan penelitian survey deskriptif analitik yaitu suatu metode yang dilakukan untuk mencari hubungan antara variable independen dengan variable dependen dengan desain penelitian cross sectional. Penelitian ini dilakukan di ruang rawat ibu BLUD Rumah Sakit Ibu Dan Anak Banda Aceh pada tanggal 5-6 April 2016.

Pengambilan sampel yang digunakan dalam penelitian ini adalah accidental sampling yaitu seluruh ibu nifas yang memiliki bayi yang berumur 0-3 hari dengan tujuan untuk mengetahui onset laktasi di BLUD Rumah Sakit Ibu Dan Anak Banda Aceh maka jumlah sampel dalam penelitian ini adalah sebanyak sampel yang didapat selama 2 hari. Analisis data menggunakan uji statistik Chi Square Test dengan taraf kepercayaan 95\%

\section{HASIL DAN PEMBAHASAN}

Berdasarkan penelitian yang dilaksanakan tanggal 5-6 April 2016 terhadap 32 orang ibu nifas di Ruang Rawat Ibu BLUD RSIA mayoritas mengalami onset laktasi (masa pengeluaran ASI) dalam kategori 0-3 hari yaitu sebanyak $32 \mathrm{ibu}(84.4 \%)$.

Pada analisis bivariat didapat gambaran karakteristik penelitian yaitu onset laktasi sebagai variabel terikat dan variabel paritas, metode persalinan sebagai variabel bebas.

Analisis bivariat menggunakan uji chi_square yang bertujuan untuk mengetahui hubungan variabel paritas dan metode persalinan dengan onset laktasi. Hasil analisis bivariat tersebut disajikan pada tabel 1. sebagai berikut: 
Tabel 1. Hasil Analisis Bivariat Faktor-Faktor yang Berhubungan dengan Onset Laktasi pada Ibu Nifas 0-3 Hari Di Ruang Rawat Ibu BLUD Rumah Sakit Ibu dan Anak Banda Aceh Tahun 2016

\begin{tabular}{|c|c|c|c|c|c|c|c|}
\hline \multirow[t]{2}{*}{ Variabel Independen } & \multicolumn{4}{|c|}{ Onset Laktasi } & \multicolumn{2}{|c|}{ Total } & \multirow[t]{2}{*}{ P-Value } \\
\hline & 0-3 hari & $\%$ & $>3$ hari & $\%$ & $\mathbf{f}$ & $\%$ & \\
\hline \multicolumn{8}{|l|}{ Paritas } \\
\hline 1. Primipara & 10 & 90.9 & 1 & 9.1 & 11 & 100 & \multirow{3}{*}{0.718} \\
\hline 2. Multipara & 10 & 83.3 & 2 & 16.7 & 12 & 100 & \\
\hline 3. Grandemultipara & 7 & 77.8 & 2 & 22.2 & 9 & 100 & \\
\hline \multicolumn{8}{|l|}{ Metode Persalinan } \\
\hline 1. Normal & 25 & 92.6 & 2 & 7.4 & 27 & 100 & 0.018 \\
\hline 2. Sectio Cesarea & 2 & 40.0 & 3 & 60.0 & 5 & 100 & \\
\hline
\end{tabular}

Sumber : Data primer (diolah tahun 2016)

\section{Pembahasan}

1. Hubungan Paritas dengan Onset Laktasi

Hasil uji statistik (uji chi-square), diperoleh nilai $\mathrm{p}=0.718(\mathrm{P}>0.05)$ artinya hipotesa alternatif peneliti diterima yaitu tidak ada hubungan yang bermakna antara paritas dengan onset laktasi pada ibu nifas di Ruang Rawat Ibu BLUD RSIA tahun 2016. Hasil analisis hubungan menunjukkan bahwa onset laktasi 0-3 hari lebih sedikit dijumpai pada ibu nifas dengan paritas grandemultipara yaitu 7 ibu (77.8\%) dibandingkan ibu paritas primipara dan multipara $10 \mathrm{ibu}$.

Hasil penelitian ini tidak sejalan dengan penelitian yang dilakukan oleh Ekstrom et al. (2003) menunjukkan bahwa pada ibu multipara mempunyai periode lebih panjang dalam memberikan ASI untuk bayinya dibandingkan dengan ibu primipara. Bayi dari ibu primipara biasanya lebih banyak yang menerima pengganti ASI yaitu sekitar 22,2\% dibandingkan bayi-bayi dari ibu multipara, dimana pemberian pengganti ASI tersebut tanpa didasari indikasi medis.

Penelitian Torres et al (2010) di Spanyol mengungkapkan bahwa dengan pemberian ASI dari donor akan menurunkan pemberian susu formula pada 28 hari pertama kehidupan neonatus sekitar 37\% pada tahun 2008, dibandingkan tahun 2006 sekitar 60\% neonatus yang menerima susu formula pada hari pertama kehidupan.

Pemberian pengganti ASI tanpa alasan medis berhubungan dengan kepercayaan diri ibu untuk memberikan ASI pada bayinya, ibu merasa tidak yakin bahwa produksi ASI dapat mencukupi kebutuhan bayinya. Hasil penelitian ini menjelaskan bahwa pemberian 
pengganti ASI akan menurunkan durasi pemberian ASI. Pemberian penganti ASI berhubungan dengan praktek di tempat persalinan. Pemberian pengganti ASI pada hari pertama disebabkan oleh onset laktasi yang terhambat atau ASI belum keluar (Hruschka et al., 2003).

Meskipun pada ibu multipara mempunyai pengalaman dalam mengasuh bayinya dibandingkan dengan ibu primipara, dan tentunya sangat berpengaruh terhadap pemberian ASI (Sakha and Behbahan, 2005).

Onset laktasi berhubungan dengan produksi ASI dan pengenalan atau pemberian pengganti ASI sebelum ASI keluar. Ibu yang kurang memahami proses pembentukan ASI dan mengalami onset laktasinya terlambat atau lebih dari 3 hari akan kehilangan kepercayaan diri mereka untuk memproduksi ASI yang lebih banyak, sehingga mereka tidak yakin bahwa bayinya dapat bertahan dengan pengeluaran kolostrum yang sangat sedikit pada hari pertama setelah lahir. Kehilangan kepercayaan tersebut akan semakin memperlambat onset laktasi sehingga meningkatkan risiko untuk memberikan prelakteal dengan susu formula atau makanan berbahan cair lainnya. Pemberian prelakteal tersebut akan mengurangi frekuensi dan durasi bayi mengisap payudara ibunya dan meningkatkan risiko penghentian dini pemberian ASI pada bayi (Hruschka et al., 2003).

Pelaksanaan donor ASI atau bank ASI Di Indonesia masih belum dilaksanakan, sehingga ibu yang belum keluar ASI akan memberikan cairan pengganti ASI ataupun susu formula untuk bayinya dan itu merupakan suatu kegagalan yang menghambat dalam keberlangsungan pemberian ASI eksklusif.

Asumsi peneliti, seorang ibu primipara akan mengalami masalah pada proses produksi ASI dikarenakan ibu yang kurang memahami proses pembentukan ASI dan faktor hormonal yang belum stabil di hari-hari pertama persalinan, ditambah lagi ibu kehilangan kepercayaan diri mereka untuk memproduksi ASI yang lebih banyak, dikarenakan secara fisiologis ASI mengalami pengeluaran sedikit. Hal inilah yang menyebabkan onset laktasinya terlambat atau lebih dari 3. Disamping itu adanya persepsi yang salah dimana ibu mendengar ada pengalaman menyusui yang kurang baik dari orang lain sehingga memungkinkan ibu untuk ragu dalam memberikan ASI kepada bayinya. Hal yang sama juga akan terjadi pada ibu-ibu yang sudah pernah menyusui sebelumnya, dimana diakibatkan oleh persepsi ibu tentang ASI yang salah. 


\section{Hubungan Metode Persalinan dengan Onset Laktasi}

Hasil uji statistik (uji chi-square), diperoleh nilai $\mathrm{p}=0.018 \quad(\mathrm{P}<0.05)$ artinya hipotesa altenatif peneliti diterima yaitu ada hubungan yang bermakna antara metode persalinan dengan onset laktasi pada ibu nifas di Ruang Rawat Ibu BLUD RSIA tahun 2016. Hasil analisis hubungan menunjukkan bahwa onset laktasi 0-3 hari lebih banyak dijumpai pada ibu nifas dengan metode persalinan normal yaitu 25 ibu (92.6\%) dibandingkan ibu dengan metode persalinan seksio sesarea yaitu $2 \mathrm{ibu}(40.0 \%)$.

Hasil penelitian ini didukung oleh penelitian yang dilakukan Chien and Tai (2007) bahwa wanita yang melahirkan dengan menggunakan metode sectio secarea hanya sekitar $14,2 \%$ yang mengalami pengeluaran ASI segera sementara 85,8\% pengeluaran ASI terjadi di hari ke empat post partum. Selain itu dilaporkan juga bahwa wanita yang menjalani proses persalinannya dengan metode sectio secarea mempunyai pengalaman lebih lambat dalam inisiasi menyusui. Penelitian yang dilakukan oleh Chien and Tai (2007) pada kalangan masyarakat kelas tinggi di Cina, dimana tingkat persalinan dengan sectio secarea sangat tinggi menunjukkan hubungan yang negatif antara metode persalinan sectio secarea dengan pemberian ASI. Hasil penelitian menunjukkan bahwa metode persalinan sectio secarea merupakan faktor risiko terhadap proses pengeluaran ASI.

Penelitian ini didukung oleh pendapat Ekstrom (2003), ibu yang melahirkan dengan tindakan Seksio sesarea tentunya akan mengalami masalah-masalah yang berbeda dengan ibu-ibu yang melahirkan secara normal. Efek anestesi, rasa nyeri pada luka operasi, gangguan mobilisasi dan perasaan gagal dalam proses persalinan akan dirasakan oleh ibu-ibu yang melahirkan dengan SC. Sedangkan pada ibu yang melahirkan secara normal dapat memproduksi ASI yang cukup sesuai dengan kebutuhan bayi atau bahkan produksi ASI-nya berlebih sehingga perlu dibuang supaya tidak terjadi bendungan ASI.

Penelitian Dewey (2001) menunjukkan bahwa ibu-ibu dengan tindakan SC akan mengalami hambatan dalam memberikan ASI dikarenakan oleh faktor kecemasan ibu terhadap kondisinya maupun kondisi bayinya yaitu dari hasil penelitian sebanyak $63 \%$ ibu memutuskan untuk memberikan susu formula karena ASI-nya tidak keluar.

Berbeda dengan kondisi di atas, menurut Rusli (2008), tidak sedikit ibu postpartum dengan tindakan SC kolostrum atau ASI-nya tidak keluar. Hal tersebut menyebabkan ibu merasa khawatir dengan keadaan bayinya sehingga banyak ibu yang memutuskan untuk memberikan makanan prelaktal pada bayinya. 
Menurut Edmond (2006), faktor yang dapat menghambat produksi ASi adalah perasaan takut, cemas, sedih, merasa kesal. Bila ibu stress dan cemas maka akan terjadi suatu hambatan dari let down reflex. Hal tersebut terjadi karena adanya pelepasan epinefrin yang menyebabkan vasokontriksi dari pembuluh darah alveoli, sehingga oksitosin terhambat untuk mencapai target organ yaitu mioepitelium. Akibat dari let down reflex yang tidak sempurna menyebabkan bendungan ASI dan akhirnya mengahambat hormon prolaktin untuk memproduksi ASI.

Asumsi peneliti, kualitas dan kuantitas ASI dapat dipengaruhi proses persalinan. Proses persalinan yang normal sangat mendukung dalam pengeluaran ASI khususnya satu jam atau lebih setelah persalinan dikarenakan persalinan yang normal akan memudahkan ibu langsung berinteraksi segera dengan si bayi. Proses onset laktasi antara persalinan normal dan SC memang berbeda, pada ibu yang melahirkan dengan cara sectio sesarea sering kali sulit menyusui bayinya segera setelah ia lahir, terutama jika ibu diberikan anastesi umum. Ibu relatif tidak sadar untuk dapat mengurus bayinya di jam pertama setelah bayi lahir. Meskipun ibu mendapat anastesi epidural yang membuatnya tetap sadar, kondisi luka operasi di bagian perut relatif membuat membuat onset laktasi sedikit lama dan terganggu.

\section{KESIMPULAN}

Setelah dilakukan penelitian dan dilakukan uji statistik tentang hubungan paritas dan metode persalinan dengan onset laktasi pada ibu nifas di RSIA BLUD Rumah Sakit Ibu dan Anak tahun 2013dengan jumlah responden sebanyak 32 orang, maka dapat disimpulkan bahwa :

1. Tidak ada hubungan yang bermakna antara paritas dengan onset laktasi pada ibu nifas, dimana diperoleh nilai $\mathrm{p}=0.718(\mathrm{P}>0.05)$.

2. Terdapat hubungan yang bermakna antara metode persalinan dengan onset laktasi pada ibu nifas, dimana diperoleh nilai $\mathrm{p}=0.018(\mathrm{P}<0.05)$.

\section{SARAN}

1. Kepada Dinas Kesehatan diharapkan dapat mengambila kebijakan peraturan dengan mewajibkan setiap tempat persalinan harus melaksanakan Inisiasi Menyusu Dini serta menfasilitasi ibu untuk menyusu bayinya pada setiap persalinan. Setiap penolong wajib 
melaksanakan Inisiasi Menyusu Dini pada setiap persalinan. Perlu adanya program donor ASI dan bank ASI untuk mendukung keberhasilan program ASI Eksklusif, sehingga ibu yang mengalami onset laktasi > 3 hari PP tidak memberikan cairan pengganti ASI kepada bayinya.

2. Kepada Bidan diharapkan perlu melakukan upaya pendekatan komunikasi, informasi dan edukasi (KIE) bagi ibu sejak awal kehamilan dalam antenatal care tentang pentingnya hal-hal yang berkaitan dengan keberhasilan menyusu, proses laktasi dan cara menyusui yang benar terutama pada ibu primigravida dan onset laktasinya lebih dari 3 hari postpartum.

\section{DAFTAR PUSTAKA}

Asiyah, S. (2010). Karakteristik Bayi Berat Lahir Rendah (BBLR) Sampai Tri Wulan II.Tahun 2009. Kediri.

Budiarto, (2001). Biostatistik Untuk Kedokteran Dan Kesehatan Masyarakat. EGC, Jakarta.

Chapman DJ. Peres-Escamilla R: Identification of risk factors for delayed onset of laction. $\mathbf{J}$ Am Diet Assoc 99:450-454. 1999

Dewey K. (2001). Maternal and fetal stress are assocated with impaired lactogenesis in human, journal of nutrition.

(2002). Risk Factors For Suboptimal Infant Breastfeeding Behavior, Delayed Onset of Lactation, and Excess Neonatal Weight Loss

(2013). Risk Factors For Suboptimal Infant Breastfeeding Behavior, Delayed Onset of Lactation, and Excess Neonatal Weight Loss

Edmond KM, Zandoh C, Quigley MA, Amenga- Etego S, Owusu-Agyei S, Kirkwood BR. Delayed Breastfeeding initiation increases risk of neonatal mortality. Pediatriss 2006

Ekstrom, A., Widstrom, A.M. \& Nissen, E. (2003) Duration of breastfeeding in Swedish primiparaous and multiparaous women. J Hum Lact, 19 (2):172-178.

Grajeda R. Perez-Escamilla R: Stress during labor and delivery is associated wit delayed onset of lactation amongurban Guatemalan women. J Nurt 132: 3055-3060. 2002

Hartini, E.E. (2011). Pengaruh Onset Laktasi Terhadap Praktik Pemberian ASI Pada Neonatus. Palangkaraya.

Hruschka, D. J. Sellen, D. W. Stein, A. D. dan Martorell, R. (2003) Delayed Onset Of Lactation and Risk of Ending Full Breast - Feeding Early In Rural Guatemala. J. Nutr. 1332592-99.

Hildebrandt H: Maternal perception of lactogenesis time and clinical report. J Hum Lac 15: 317-323. 1999 
Khassawneh, M. Khader, Y. Amatin, Z. dan Alkafajei, A. (2006), Knowledge, Attitude and Practice of Breasfeeding in the North of Jordan : A Crossectional study. Int Breasfeeding

Nurliawaty. (2010). Faktor- faktor Yang Berhubungan Dengan Produksi ASI Pada Ibu Post SC Tasikmalaya 2010

Notoadmojo S., 2005, Metodologi penelitian Kesehatan, Rineka Cipta, jakarta.

Notoatmodjo, S. (2010). Ilmu Kesehatan Masyarakat. Rineka Cipta, Jakarta

Riskesdas. (2010). Riset Kesehatan Dasar 2010. Jakarta: Departemen kesehatan Republik Indonesia.

Roesli, U. (2008) Inisiasi Menyusu Dini Plus Asi Eksklusif. Jakarta: Pustaka Bunda.

Sakha, K. \& Behbahan, A.G.G. (2005) The onset time of lactation after delivery. Medical Journal of The Islamic Republic of Iran, 19(2):135-139.

Sistiarani, C. (2008). Faktor Martenal Dan Kualitas Pelayanan Antenatal yang Beresiko Terhadap Kejadian Berat Badan Lahir Rendah (BBLR) di RSUD Banyumas.

UNICEF. (2007). Initiation of Breastfeeding. By Breast Crawl. UNICEF

Wulandari. (2012). Tingkat Pengetahuan Ibu Nifas Tentang Bendungan ASI di RB Annur Sumber Surakarta. 